\title{
Development of Interactive Multimedia on Learning Descriptive Text for French Learners in North Sumatra
}

\author{
Nurilam Harianja ${ }^{1}$, Tengku Ratna Soraya ${ }^{2}$, Hesti Fibriasar ${ }^{3 *}$ \\ 1,2,3 Departement of French Language Education, Universitas Negeri Medan, Indonesia \\ Email: nurilam@unimed.ac.id; tengkuratna@unimed.ac.id; hesti@unimed.ac.id
}

\begin{abstract}
Pandemic where the learning process cannot be done directly or face to face, especially in foreign language learning, especially French in class $X$ in first semestre students who should receive the most basic French language learning. An interactive multimedia for French Learners in North Sumatra using Adobe flash professional CS6 software which aims to improve student motivation and learning outcomes in writing descriptive text material contained in the learning objectives decrire une personne et une chose. Interactive multimedia that is developed and implemented in learning is very important because it has been proven to be feasible and effective. The object of this research is the students of class X at SMA 21 Medan. The purpoese of the research is to develop interactive multimedia on descriptive text material for French learners in Notrh Sumatra and knowing the effectiveness of interactive multimedia products based on Adobe Flash Professional CS 6 to improve the ability to write descriptive text of students of SMA Negeri 21 Medan. This research was conducted using the

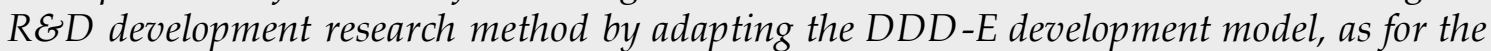
interactive multimedia development steps for learning descriptive text writing skills for students of class XI SMA as follows: (1) Decide, (2) Design (product design), (3) Development (product development), (4)) Evaluation (product test). To obtain data validity, validation of media experts and material experts. To obtain data validity, validation of media experts and material experts is required with the following results: (1) material validation shows the eligibility percentage is $88.5 \%$ in the very good category (2) media validation shows the Feasibility percentage is $87.3 \%$ with the very good category. The results of individual trials were declared "very good" with an average percentage of $82.7 \%$. The results of small group trials were stated to be "very good" with an average percentage of $86.3 \%$ and the results of limited field trials were declared "very good" with an average percentage of $88.5 \%$. Then, the effectiveness of interactive multimedia products is seen from the increase in student learning outcomes in descriptive text material before and after using interactive multimedia. There is a difference in value 22.30. This Interactive multimedia that is feasible and effective is used as a medium for teaching French in high school, especially class $x$ semester 1, which must acquire basic French knowledge with a precise and interesting process during the Covid 19 pandemic.
\end{abstract}

Keywords: interactive multimedia; descriptive text; french lesson; students

\section{Introduction}

The learning process in schools is the best public policy tool as an effort to increase knowledge and skills (Persel, CH: 1979), it is also what is embedded in the minds of most students, that school is the most exciting vehicle for playing, interacting and building relationships and social awareness. Schools are also the center of interaction between teachers and students in improving knowledge, skills and instilling attitudes and character, but all these processes must be stopped suddenly when the school is sudenly closed. 
On December 31, 2019, a virus known as The Corona Virus Disease 2019 (COVID19) was reported by the WHO China office to have an outbreak in the city of Wuhan, China. The virus which is known to have a very high transmission rate is spreading so rapidly to several countries in almost all parts of the world. Until March 11, 2020, WHO declared COVID-19 a global pandemic. The COVID-19 pandemic has infected more than 4,248,389 people with 294,046 confirmed deaths in 202 countries as of 14 May 2020 (WHO, 2020). This pandemic has destroyed social life and forced billions of people to stay in their homes. The COVID-19 pandemic has disrupted all areas of life, including education at all levels (Daniel, 2020). In Indonesia, the government made a sudden decision by closing all kinds of activities in schools including learning activities and moving them to learning at home through distance education. The imperative to implement social distancing policies, work form home and learn from home to stop the spread of Covid 19, has led to a shift in the paradigm of education in Indonesia during this pandemic. A very real impact in the world of education, namely the occurrence of disruption of technology as a shift in the direction of learning, from usually carrying out face-to-face learning, has now drastically turned into online or online-based learning without doing face-to-face learning. This is certainly the background for the issuance of Circular Number 4 of 2020 on March 24, by the Minister of Education and Culture of the Republic of Indonesia as a policy for implementing education in the emergency period of the Spread of Coronavirus Disease. In Circular No. 4 of 2020, there are six important new policy points in the world of education, which have been clearly explained, including those related to the National Examination, PPDB, School and Graduate Examinations, Class Advancement, BOS Funds and the fundamentals of all these points. is changing the learning process between educators and students by carrying out teaching and learning activities from home. The policy of learning from home through online / distance learning is implemented to provide meaningful learning experiences for students, without being burdened with demands to complete all curriculum achievements for grade promotion and graduation (Mendikbud RI, 2020).

In modern times, distance education is becoming a more popular and accepted approach to education (Yilmaz, 2015). Online media or also called E-learning which is popular nowadays is distance learning that can be accessed in various ways (Syakur, 2020). The use of technology media provides benefits for teachers and students to access learning materials and interact directly in learning in the classroom, and also outside the classroom through online media (Prasasti, 2019). In addition, today digital technology has become an inseparable part of the world of education (Benson \& Kolsaker, 2015). Students can use digital technology for learning activities such as reading and sending emails, accessing learning management systems, reading journals or e-books, taking online quizzes, participating in discussion forums, and so on. On this basis, online learning (e-learning) can be one way to carry out distance learning in the midst of the COVID-19 Pandemic. Online learning is a part of distance education, which is defined as the delivery of formal instructions where time and geographic location separates students from their educators (Holmberg, 2005); (Moore, Verduin, \& Clark, 1992). Online learning through virtual classrooms can be an alternative so that learning activities can continue during the COVID-19 epidemic (Y.- M. Ng \& Peggy, 2020). Online learning can be done with virtual classrooms, which are learning experiences in a synchronous or asynchronous environment using various devices (such as laptops or smartphones) with internet access (Zhu \& Liu, 2020). Various platforms are used to help facilitate the learning process which serves as a medium for delivering material, assessments, or for submitting assignments. These platforms include Whatsapp Group, Zoom Cloud Meeting, Google Classroom, Google Meet, Google Form, and e-mail. 
Learning text is considered important because it will form the construction of students' thinking more coherently or systematically. In addition, text is considered to be functional, namely the use of language that can never be separated from the context because in the form of the language used it reflects the ideas, attitudes, values and ideology of its users. The process of producing text (writing) is considered difficult compared to other language skills because in writing it puts forward receptive elaboration (listening and reading), and then it leads to the production of ideas into words. One of the texts studied in learning French in high school is a descriptive text which is contained in the learning objectives in grade X SMA with the material "la description d'une chose ou d'une personne".

Based on the results of observations and interviews conducted with French class X SMAN 21 Medan teachers, Mrs. Nuriyati, S.Pd and Mrs. Rini Endang Lestari, S.Pd revealed that the average value of daily tests in French, especially in writing descriptive text What is included in the learning objectives in class X SMA with the material "la description d'une chose ou d'une personne" is 60 with $60 \%$ completeness. Meanwhile, the standard KKM set was 75 . In reality, only $60 \%$ of students were able to achieve the KKM score. This condition shows that students' understanding in the learning process of writing descriptive texts contained in the material "la description d'une chose ou d'une personne" is still low, which causes student learning outcomes to tend to be low. In addition, the results of interviews with students obtained information that students had difficulty learning descriptive text writing material because of the lack of teaching media for writing descriptive text that could be used as a writing reference.

Because the focus of this research is to produce media products capable of delivering descriptive text material with the theme "decrier une personne et une chose" to class X first semester students, most of whom have never studied French, this multimedia must be developed in such a way, presenting an overview. which is very real equipped with correct pronunciation and introductory material delivered in Indonesian, so that the students' imagination to write descriptive text in French becomes focused and does not eliminate the real meaning of learning. One program that can be used to create learning media that contains animated images, graphics, text, sound and so on is Adobe Flash CS 5. According to Palelupu (2014: 11) Adobe Flash CS6 is an animation program that has been widely used by animators. to produce professional animation. Learning media made from these programs are more often found for subject matter which is dominated by pictures.

Adobe Flash CS6 software is a software that can be used for multimedia development or development. Adobe Flash CS6 is a graphic and animation program whose existence is intended for design and animation lovers to create interactive web animations, animated cartoon films, business presentations or activities, company / organization profiles and interesting flash games. According to Emut (in Yunita 2017: 4) This software is based on vector animation which can be used to produce web animation, presentations, games, films and interactive learning CDs. This media also combines and synergizes all media consisting of text, graphics, photos, videos, animation, music, narration and programmable interactivity based on learning theory. In general, the benefits that can be obtained from multimedia are that the learning process is more interesting, more interactive, the amount of teaching time can be reduced, the quality of student learning can be improved and the teaching and learning process can be carried out anywhere and anytime, and student learning attitudes can be improved. 


\section{Research Methods}

The research was conducted at SMA Negeri 21 Medan. When the research was carried out in June-November 2020. This research used research and development methods or in other terms is Research and development $(\mathrm{R} \& \mathrm{D})$. This research method is used to produce certain products and test the effectiveness of these products (Sudaryono, 2013: 11). In this study, researchers used the DDD-E model (Decide, Design, Develop, Evaluate). This model is one of the learning design models used in developing multimedia learning. The choice of this model is also based on the development model procedure which is considered simpler than other development models. However, even though it is considered simple, the steps listed in this development model contain the entirety of the general research and development procedures that must be carried out by researchers. This mixed research method uses a repeated survey data format using a sample of instructional media design experts and learning material experts, then a separate evaluation is carried out from the control sample and the experimental sample. The data analysis technique used is descriptive analysis technique. The descriptive analysis technique was carried out using descriptive statistics. According to Sugiyono (2012: 207) Descriptive statistics are statistics used to analyze data by describing or describing the data that has been collected as it is without intending to make generalized conclusions or generalizations. The data obtained is data about the validation of interactive learning media in writing descriptive text lessons in high school. This data was collected through validation of material experts, validation of instructional design experts (media experts) and questionnaires were given to French teachers in class X IPS 1 and X IPS 2, SMAN 21 Medan. Validation questionnaires are given to validators, individual trials, small group trials, and limited group trials presented in the form of a Likert scale that has been given a score as shown in the following Likert scale table.

Table 1. Group Score following Likert Scale

\begin{tabular}{|l|l|l|}
\hline No & Answer Criteria & Score \\
\hline 1 & Very Good & 5 \\
2 & Good & 4 \\
3 & Good Enough & 3 \\
4 & Deficient & 2 \\
5 & Not Good & 1 \\
\hline
\end{tabular}

Then the data were analyzed using descriptive statistics (average score and percentage), namely calculating the percentage of indicators for the use of interactive multimedia for each category on the media that had been developed. The percentage of this score can be calculated using the following calculation formula.

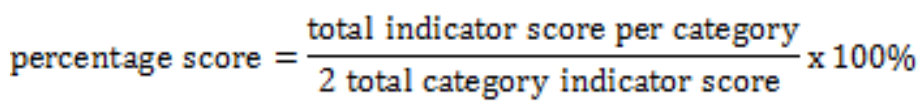

The calculation of research data using the formula above will produce a figure in the form of a percent $(\%)$. The score classification is then changed to a classification in the form of a percentage (Sugiono, 2012: 137) and then interpreted with a qualitative sentence listed in table 2 below. 
Table 2. Criteria for the Percentage of Learning Media Indicators

\begin{tabular}{|c|l|l|}
\hline No & $\begin{array}{l}\text { Criteria } \\
\text { percentage }\end{array}$ & \multicolumn{1}{|c|}{ interval } \\
\hline A & $\begin{array}{c}81 \% \leq \mathrm{X} \leq \\
100 \%\end{array}$ & Very Good \\
B & $61 \% \leq \mathrm{X} 80 \%$ & Good \\
C & $41 \% \leq \mathrm{X}<60 \%$ & Moderate \\
D & $21 \% \leq \mathrm{X}<40 \%$ & Not good \\
E & $0 \% \leq \mathrm{X}<20 \%$ & Not very good \\
\hline
\end{tabular}

Sugiyono, 2012: 137

After presenting in percentage form, the next step is to determine the feasibility level of the media based on the results of the tests that have been carried out. To determine the feasibility category of this learning media, a Likert scale measurement was used.

Then the effectiveness of interactive multimedia in learning to write descriptive texts contained in the material "la description d'une chose ou d'une personne" can be seen based on student learning outcomes. Student learning outcomes are obtained from the writing performance test scores in writing descriptive texts contained in the material "la description d'une chose ou d'une personne". Student learning outcomes are carried out in two stages, namely by doing pretest and posttest. When the end result of student learning after using interactive multimedia increases, multimedia can be said to be effective in the learning process.

\section{Results and Discussion}

\subsection{Results}

The results of this study are multimedia products that are feasible and effective in the learning process. The feasibility value is obtained from assessors of media design experts and learning material experts. Then the effectiveness value is obtained from the increase in student learning outcomes before and after the application of interactive multimedia. The following is a complete explanation of the feasibility and effectiveness of the multimedia.

The learning media developed have been declared fit for use in learning because the media has met the product quality criteria. There are 4 stages carried out in the trial of this product, including: (1) Validation of material experts, instructional media experts, and French teachers at SMAN 21 Medan; (2) Individual trials with three students with homogeneous abilities; (3) Small group trials with nine students with homogeneous abilities; and (4) Limited field trials with thirty-five students.

\section{a. Validation Results of Media Experts and Learning Material Experts}

Validators for learning media experts, researchers entrust experts in the field of Informatics and Computer Engineering who are lecturers of the Informatics and Computer Engineering Study Program at the State University of Medan. The purpose of the media expert validation is so that the resulting product is really related to the learning concept at school, so that the product is suitable for use in the learning process at school. The instructional media expert gives a score on each indicator, then fills in notes or comments in 
general to revise the improvement of learning media. The assessment aspects in the media expert validation sheet instrument consist of aspects of guidance and information, software operations as well as systematics, aesthetics and media principles. The indicators in the validation sheet consist of 38 indicators. Performed 3 times in accordance with the direction of the instructional media design expert. The revised results of all errors in learning media are reviewed by the media expert validator at the third meeting, then the validator provides an assessment on the validation sheet instrument. The result of the calculation of the percentage score of the instructional media experts at the third meeting was $87.3 \%$ with a very good classification. Validation at this meeting learning media experts gave positive responses to learning media. Learning media experts responded that the learning media products produced were good, the design was firm and could be adapted to the learning process in the classroom. The assessment of descriptive text learning media in terms of material was assessed by lecturers of the French language education study program and teaching at the Medan State University Postgraduate Program and is an expert in the fields of linguistics and French language education.

The purpose of material expert validation is so that the content of the material in the learning media is in accordance with $\mathrm{KI}$ and $\mathrm{KD}$, factualization of material content, usefulness of learning material, conformity of material to student needs and quality of presentation in conveying material concepts. The results of the assessment of learning media conducted by the teacher obtained the overall average result of $91.2 \%$ with very good criteria with a score of 229 out of a maximum total of 250 . The percentage comparison of each expert can be seen in figure 1 below.

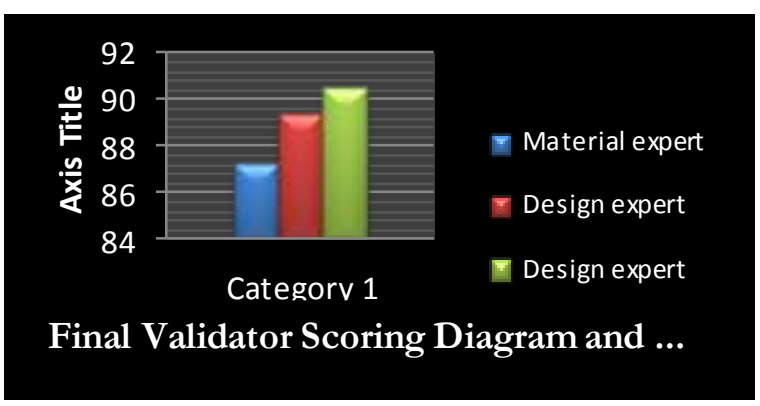

Figure 1. The Percentage Comparison of Each Expert

The conclusion from the results of the responses of class X SMAN21 Medan students, namely Interactive Multimedia on learning to write descriptive texts contained in the material "la description d'une chose ou d'une personne" which has been developed is declared feasible and meets needs with the overall criteria "Very Good". This means that the learning media developed has increased development and can meet the demands of learning needs. More details, the results of data acquisition are shown in the graphic diagram in figure 2 below.

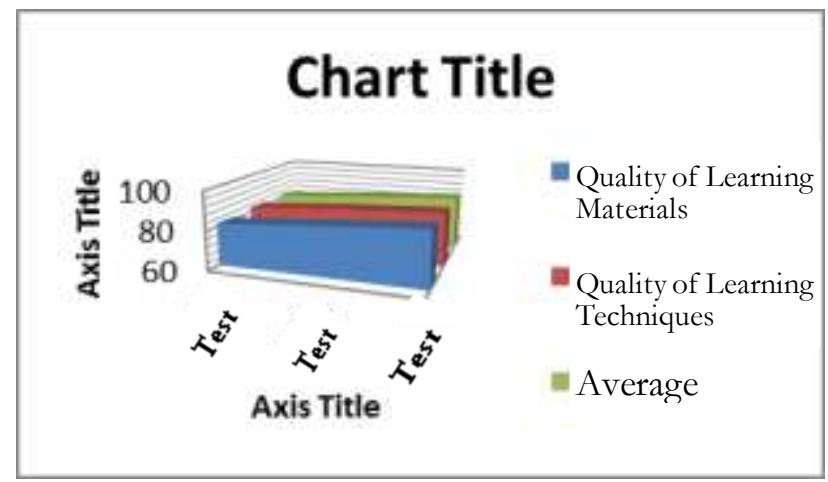

Figure 2. The Effectiveness of Interactive Multimedia in Descriptive Text 
The effectiveness of interactive multimedia in learning to write descriptive texts contained in the material "la description d'une chose ou d'une personne" can be seen based on student learning outcomes. Student learning outcomes are obtained from the writing performance test scores in writing descriptive texts contained in the material "la description d'une chose ou d'une personne". Student learning outcomes are carried out in two stages, namely by doing pretest and posttest. Data about student learning outcomes can be seen in table 4 below.

Table 4. Student Learning Outcomes

\begin{tabular}{|c|c|c|}
\hline $\begin{array}{c}\text { Student Serial } \\
\text { Number }\end{array}$ & Pretest & Postest \\
\hline 1 & 62 & 87 \\
\hline 2 & 62 & 80 \\
\hline 3 & 62 & 87 \\
\hline 4 & 75 & 93 \\
\hline 5 & 75 & 93 \\
\hline 6 & 64 & 87 \\
\hline 7 & 62 & 93 \\
\hline 8 & 74 & 93 \\
\hline 9 & 62 & 93 \\
\hline 10 & 62 & 87 \\
\hline 11 & 75 & 93 \\
\hline 12 & 62 & 87 \\
\hline 13 & 52 & 86 \\
\hline 14 & 75 & 93 \\
\hline 15 & 75 & 93 \\
\hline 16 & 67 & 93 \\
\hline 17 & 75 & 87 \\
\hline 18 & 75 & 93 \\
\hline 19 & 61 & 87 \\
\hline 20 & 61 & 87 \\
\hline 21 & 61 & 79 \\
\hline 22 & 56 & 75 \\
\hline 23 & 75 & 93 \\
\hline 24 & 61 & 85 \\
\hline 25 & 61 & 90 \\
\hline 26 & 67 & 90 \\
\hline 27 & 67 & 93 \\
\hline 28 & 74 & 87 \\
\hline 29 & 67 & 93 \\
\hline 30 & 74 & 93 \\
\hline 31 & 67 & 93 \\
\hline 32 & 50 & 86 \\
\hline 33 & 74 & 87 \\
\hline
\end{tabular}




\begin{tabular}{|c|c|c|}
34 & 75 & 93 \\
\hline 35 & 75 & 93 \\
\hline Total & $\mathbf{2 3 4 2}$ & $\mathbf{3 1 . 2 2}$ \\
\hline Average & $\mathbf{6 6 . 9 0}$ & $\mathbf{8 9 . 2 0}$ \\
\hline
\end{tabular}

Based on the table above, the data obtained shows that student learning outcomes before using interactive multimedia in learning to write descriptive text contained in the material "la description d'une chose ou d'une personne" obtained an average score of 66.90 with the category "Enough" meaning The value achieved by students needs to be improved again, while student learning outcomes after using interactive multimedia in learning to write descriptive texts contained in the material "la description d'une chose ou d'une personne" obtained an average score of 89.20 with the category "Very Good "means that the students' scores are better than before, with a difference of 22.30 . Thus interactive multimedia products in learning to write descriptive texts contained in the material "la description d'une chose ou d'une personne" are effectively used to improve student learning outcomes in class X SMAN 21 Medan.

\subsection{Discussion}

Learning media is an intermediary tool or tool that can facilitate the delivery of information or lesson content to students. According to Rusman (2012: 60), learning media is a tool or form of stimulus that functions to convey learning messages. Heinich (in Sutirman, 2013: 15) suggests media as an intermediary that delivers information from the source to the recipient. Thus, television, films, photographs, radio, audio recordings, projected images, printed materials, and the like are classified as media. If the media carries messages or information containing the aims and objectives of teaching, the media is called learning media. Learning media is not just an introduction to material, but also a means of arousing imagination, interest, and a pleasant atmosphere. Media can arouse the enthusiasm for learning that enlivens the learning atmosphere so that students' understanding of teaching materials increases. This is in line with the opinion of Daryanto (2011: 6), that learning media occupies a fairly important position as a component of the learning system. Media has a very large influence on the quality of learning.

However, the fact is that there are still teachers who have not utilized the media optimally. This has happened in several schools. Teachers still use existing media without making alternative media according to student needs. This is evident from the results of interviews and teacher needs analysis questionnaires, that French teachers always use textbooks in every learning process in class, even though they state that students have very good appreciation and motivation to learn when teachers use media in the learning process. The results of the needs analysis show that $80 \%$ of students state that Indonesian language lessons that have been taking place so far tend to be ordinary, meaning that teachers explain and use textbooks more in the learning process than using other media or learning methods. Therefore, the creativity of Indonesian teachers in managing learning has a huge influence in increasing student interest and learning outcomes. In this case, the teacher can use a learning medium to create a fun learning environment. Computers are one of the tools that are still rarely used by teachers. Computers facilitate the delivery of learning because they can visualize objects that may not be in the classroom so that learning is not abstract. Computers can integrate components of writing, sound, images, moving animation, and video, so it can be said that computers are able to present information with a high level of realism. Based on the results of interviews and questionnaires to analyze the needs of teachers and students at SMA 
Negeri 21 Medan, SMA Negeri 19 Medan, and SMA 13 Medan already has adequate school facilities, such as computers that can be used as learning media.

However, teachers have not utilized these facilities for the Indonesian language learning process, even though the rapid development of information technology requires teachers to provide innovative and efficient material. One of the learning media that uses computers is interactive multimedia. Daryanto (2011:49) argues that interactive multimedia is multimedia equipped with a control device that can be operated by the user so that the user can choose what he wants for the next process. Vaughan (in Munir, 2015: 111) states that when it can follow the user's wishes, displays multimedia projects and can control what and when elements are submitted, hence what is called interactive multimedia. Interactive is a feature of multimedia programs.

Interactive multimedia is in demand by students. This is evident from the results of the needs analysis that $80 \%$ of students prefer audio-visual media such as interactive multimedia. $80 \%$ of students also stated that they felt the need to develop interactive multimedia as a learning medium in the classroom. Based on the interview, the Indonesian teacher also said that interactive multimedia as a learning medium needs to be developed to improve understanding and attract students' attention because interactive multimedia contains several components, such as text, images, animation, sound, and video that can arouse the enthusiasm for learning. Research has shown that people remember $20 \%$ of what they saw, $40 \%$ of what they saw and heard, but about $75 \%$ of what they saw, heard, and did simultaneously (Linsdstrom in Munir, 2015: 111). From this opinion it can be concluded that the appearance and sound produced causes interactive multimedia to greatly support the teaching and learning process because it is integrated with several elements, namely text, graphics, video, animation, and sound that can be seen and heard.

Based on the results of needs analysis and interviews with Indonesian teachers, one of the basic competencies that students cannot understand is the structure and language of the description text. There were $73.3 \%$ students who could not understand and $3.3 \%$ could not understand the material regarding the structure and language of the description text. $46.6 \%$ of students felt quite bored with the text description material, $50 \%$ felt ordinary, and $3.3 \%$ felt very bored. This is due to the lack of availability of instructional media, students need suitable learning methods and easy teaching materials.

In addition, the 2013 curriculum for French subjects is text-based. There are several texts that they learn so that they have to remember the structure of each text. Based on the explanation that has been described, it can be concluded that the development of descriptive text learning media needs to be designed to help the learning process of descriptive text in order to generate student motivation, facilitate understanding, and improve learning outcomes.

\section{Conclusion}

Based on the formulation, objectives, results, and interactive multimedia discussion on learning to write descriptive texts contained in the material "la description d'une chose ou d'une personne" which has been stated previously, it can be concluded as follows.

Development of interactive multimedia on learning to write descriptive texts contained in the material "la description d'une chose ou d'une personne" using adobe flash cs6 software. The development process uses the DDD-E stage (Decide, Design, Develope - 
Evaluate) from Tegeh, Decide means determining and planning the multimedia product to be produced, Design means designing multimedia making, Develop means developing, namely the activity of combining all multimedia components and finally evaluating which means evaluation of the developed interactive multimedia. The resulting product is interactive multiedia in exposition text learning which is feasible and effective to improve student learning outcomes of class X SMAN 21 Medan.

The feasibility of developing interactive multimedia in learning to write descriptive texts contained in the material "la description d'une chose ou d'une personne" is declared suitable for use in the learning process because all assessment results are in the "very good" category. The results of the validation by the material experts were declared "very good" with all aspects of the assessment getting an average of $88.5 \%$, and the results of the validation by the media design experts were declared "very good" with all aspects of the assessment getting an average of $87.3 \%$ stated "very good. good". Then the results of the response of the Indonesian language teacher with an average of $91.2 \%$ on the "very good" criteria. The results of individual trials were declared "very good" with an average percentage of $82.7 \%$. The results of small group trials were declared "very good" with an average percentage of $86.3 \%$ and the results of limited field trials were declared "very good" with an average percentage of $88.5 \%$.

The effectiveness of interactive multimedia products in learning to write descriptive texts contained in the material "la description d'une chose ou d'une personne" is seen from the results of students 'learning abilities in writing descriptive text contained in the material "la description d'une chose ou d' une personne "after using the learning media that has been developed is in the" very good "category with an average value of 89.20 and the average value before using learning media writing descriptive text contained in the material" la description d'une chose ou d "une personne" of 66.90 which is in the "good" category. This proves that student learning outcomes are higher after using interactive multimedia in learning to write descriptive text contained in the material "la description d'une chose ou d'une personne" with a difference of 22,30 which means that this value makes the developed multimedia effective to use in the French language learning process.

\section{References}

Arsyad, Azhar . 2009. Media Pembelajaran . Jakarta : Rajawali pers

Baharin, R., Halal, R., Aji, S., Yussof, I., \& Saukani, N. M. (2020). Impact of Human Resource Investment on Labor Productivity in Indonesia. Iranian Journal of Management Studies, 13(1), 139-164. https://doi.org/10.22059/ijms.2019.280284.673616

Carlsson, M, G B Dahl, B Ockert and D Rooth (2015). The Effect of Schooling on Cognitive Skills. Review of Economics and Statistics 97(3): 533-547

Fibriasari, H. 2015. The Audition Prononciation Learning Based on Multimedia in French Section of Unimed. Proceeding on Edicational Creativity and Innovation in Prespectives of The ASEAN-China Relations. 5-6 November.2015, Kang Ming Hotel, Beijing. Hal. 299-307.

Fibriasari, H. 2016. Perfectionnement du modèle d'apprentissage de l'audition prononciation. Proceeding on Conference International Sur Le Français "Le Français: en jeux linguistique, politique, economique et la culture. 3 Novembre 2016. UPI. Bandung.

Fibriasari, H. 2016. Prosodic Frequency in Signaling Linguistic Distinctions at UNIMED First Year Non-native French Students. International Journal of Humanities and Social Science Vol. 6, No. 10; October 2016. Hal 118-124.

Gerrot, L and Wignell, P. (1994). Making senseof functional grammar. Aus-tralia: Gerd 
StableHake,

Harianja, N. 2019. Youtube as the Learning Media to Improve the Speaking Skill in Expression Orale Course.Asian Themes in Social Sciences Research ISSN: 2578-5516 Vol. 3, No. 1, pp. 14-17 2019 DOI: 10.33094/journal.139.2019.31.14.17

Holmberg, B. (2005). Theory and Practice of Distance Education. In Theory and Practice of Distance Education. https://doi.org/10.4324/9780203973820

Juvrianto, Atmowardoyo, Weda. 2018. The Use of Digital Storytelling in Teaching Listening Comprehension: An Experimental Study on the Eighth Grade Students of SMP Negeri 4 Parepare . Jurnal ELT Worldwide Vol. 5 No. 1

Lavy, V(2015). Do Differences in Schools, Instrution Time Explain International Achievement Gaps? Evidence from Developed and Developing Countries. Economics Journal 125.

MacKenzie, J. S., \& Smith, D. W. (2020). COVID-19: A novel zoonotic disease caused by a coronavirus from China: What we know and what we don't. Microbiology Australia. https://doi.org/10.1071/MA20013

Maggalatung, A.S.; Aji, A.M.; Yunus, N.R. How The Law Works, Jakarta: Jurisprudence Institute, 2014.

Martin, A. (2005). DigEuLit -a European Framework for Digital Literacy: a Progress Report. Journalof ELiteracy, 2, 130-136.

Martin, A. (2006). A European framework for digital literacy. Nordic Journal of Digital Literacy, 2(1), 151-161. Retrieved from http://www.idunn.no/file/pdf/33191479/a_european_framework_for_digital_literac y.pdf

Mohammadyari, S., \& Singh, H. (2015). Understanding the effect of e-learning on individual performance: The role of digital literacy. Computers and Education. https://doi.org/10.1016/j.compedu.2014.10.025

Moore, M. G., Verduin, J. R., \& Clark, T. A. (1992). Distance Education: The Foundations of Effective Practice. The Journal of Higher Education. https://doi.org/10.2307/1982124

$\mathrm{Ng}$, W. (2012). Can we teach digital natives digital literacy? Computers and Education. https://doi.org/10.1016/j.compedu.2012.04.016

Ng, Y.-M., \& Peggy, P. L. (2020). Coronavirus disease (COVID-19) prevention: Virtual classroom education for hand hygiene. Nurse Education in Practice. https://doi.org/10.1016/j.nepr.2020.102782

Nurjanah, E., Rusmana, A., \& Yanto, A. (2017). Hubungan Literasi Digital dengan Kualitas Penggunaan E-Resources. Lentera Pustaka: Jurnal Kajian Ilmu Perpustakaan, Informasi Dan Kearsipan. https://doi.org/10.14710/lenpust.v3i2.16737

Prasasti, T.I., Solin, M., and Hadi, W. (2019). The Effectiveness of Learning Media Folklore Text of North Sumatera Based on Blended Learning by 10th Grade Students of Vocational High SchoolHarapan Mekar-1 Medan. Budapest International Research and Critics in Linguistics and Education (BirLE) Journal Vol 2 (4): 480-490.

Pratiwi, N., \& Pritanova, N. (2017). Pengaruh Literasi Digital Terhadap PsikologisAnak Dan Remaja. Semantik. https://doi.org/10.22460/semantik.v6i1p11.250

Piopiunik, M, G Schwerdt, L Simon and L Woessman (2020). Skill, signals and employability: An experimental investigation. Europan Economic Review 123: 103374

Purwanto, P.P. (2001). Penulisan bahan ajar. Jakarta: PAU-PPAI, Universitas Terbuka.

R. R (1998). Interactive engagement versus traditional methods: a six-thousand-student survey of mecha-nics test data for introductory phy-sics course [Versielektronik].The American Journal of Physics Research, Am. J. Phys,64-74.

Unité des Politiques linguistiques, Cadre européen commun de référence. Strasbourg www.coe.int/lang-CECR 
Wibowo, Agus \& Gunawan. 2015. Pendidikan Karakter Berbasis Kearifan Lokal di Sekolah. Yogyakarta: Pustaka Pelajar

Shopova, T. (2014). Digital literacy ofstudents and its improvement at the university. Journal on Efficiency and Responsibility in Education and Science, 7(2), 26-32. https://doi.org/10.7160/eriesj.2014.070201

SyahAji, R. H., Yussof, I., Saukani, M. N. M., \& Baharin, R. (2020). Does education increase labor productivity? An evidence from Indonesia during reform era. Test Engineering and Management, 82(16193), 16193-16199.

Syakur, A., Junining, E., and Mubarok, M.K. (2020). Developing English for Specific Purposes (ESP) Textbook for Pharmacy Students Using On-Line Learning in Higher Education. Britain International of Linguistics, Arts and Education (BIoLAE) Journal Vol.2 (1): 467-474.

Tang, C. M., \& Chaw, L. Y. (2015). Digital literacy and effective learning in a blended learning environment. Proceedings of the European Conference on E-Learning, ECEL, 14(1), 601-610.

Ting, Y. L. (2015). Tapping into students' digital literacy and designing negotiated learning to promote learner autonomy. Internet and Higher Education, 26, 25-32. https://doi.org/10.1016/j.iheduc.2015.04.004

WHO. Coronavirus disease., 2019 World Health Organization 2633 (2020). Yilmaz, O. (2015). The effects of "live virtual classroom" on students' achievement and students' opinions about "live virtual classroom" at distance education. Turkish Online Journal of Educational Technology, 14(1), 108-115.

Zhu, X., \& Liu, J. (2020). Education in and After Covid-19: Immediate Responses and LongTerm Visions. Postdigital Science and Education. https://doi.org/10.1007/s42438020-00126-3

Tan, L., \& Koh, J. (2014).In Self-directed learning: Learning in the 21st century education.

Wheeler, S. (2013). Digital literacies for engagement in emerging online cultures.ELC Researcj Paper Series, 5, 14-25. 